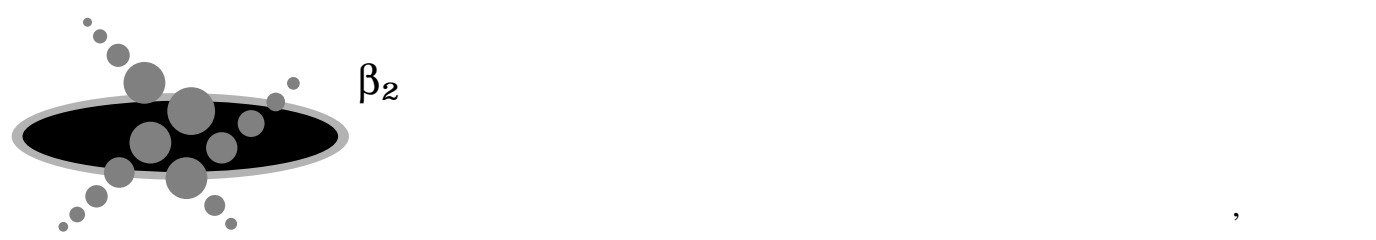

\begin{abstract}
Amyloid fibril formation is a phenomenon common to many proteins and peptides. Clarifying the mechanism of amyloid fibril formation is essential not only for understanding the pathogenesis of amyloidosis but also for improving our understanding of the mechanism of protein folding. Dialysis-related amyloidosis is a common and serious complication among patients on long-term hemodialysis, in which $\beta_{2}$-microglobulin forms amyloid fibrils. We studied the core of fibrils at single-residue resolution using recently developed H/D exchange method with the dissolution of fibrils by dimethylsulfoxide. The results suggest the mechanism of amyloid fibril formation, in which the core $\beta$-sheet formed by a minimal sequence propagates to form a rigid and extensive $\beta$-sheet network.
\end{abstract}

protein misfolding / amyloid fibril / $\beta_{2}$-microglobulin / dialysis-related amyloidosis / hydrogen/deuterium exchange / NMR

\section{1.はじめに}

タンパク質は,アミノ酸配列に従い特異的な立体構造 (ネイティブ構造) を形成して機能を発現する1).ネイ ティブ構造は, 生理的条件下においてタンパク質が形 成する唯一の安定な構造であると考えられてきた.と ころが, タンパク質は間違った構造に折りたたまり, 病 気にかかわることか明らかとなってきた2).タンパク質 の立体構造変化が原因で引き起こされる病気はコンフ オメーション病 (conformational disease) あるいは,フ オールディング病 (folding disease) とよばれ, 兴の代 表にアミロイドーシス (amyloidosis) がある. アミロ イドーシスは, アミロイド線維とよばれる細線維状構 造体が体内のさまざまな部位に沈着する疾患の総称で あり, アルツハイマー病や, プリオン病, 透析アミロイド ーシスなど 20 種類ほどが知られている31. なお, アミロ イド線維 (amyloid fibril) には, 医学用語として繊維で はなく“線維”を用いる.

アミロイド線維は光れを構成するタンパク質の種類 によらずいくつかの共通した特徴をもつ 2)-4). アミロイ ド線維は直径 5-20 nm, 長さ数 $\mathrm{mm}$ にも及、j汥分かれの ない線維であり, 線維軸と直交する方向に $\beta$ スランド (クロス $\beta$ 構造) が並んでできた細線維が, さらに何本
かより集まっている (Fig.5a) . 電子顕微鏡や原子間力 顕微鏡で観察すると, 約 $100 \mathrm{~nm}$ ごとにらせん状の周期 構造が見られる. また, アミロイド線維はコンゴーレッ ド, チオフラビン Tなどか結合すると, 特異的な分光学 的変化を示す. 前者がアミロイド線維と結合すると偏 光顕微鏡観察により黄緑色の複屈折が見られるように なるのに対し, 後者か結合した場合, $450 \mathrm{~nm}$ の励起光に よって 480-490 nmあたりに特徵的な蛍光ピークか現れ る.しかし, アミロイド線維形成タンパク質に共通した 機能やアミノ酸配列はいまだ見いだされていない.

病気とはかかわりがないさまざまなタンパク質やペ

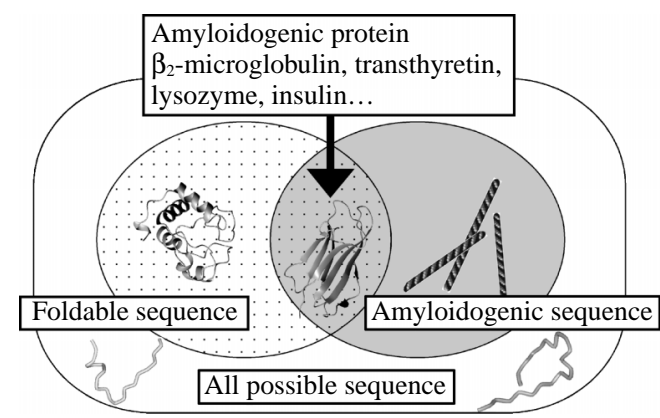

Fig.1 Relationship of the sets of foldable and amyloidogenic sequences.

\title{
Structure and Formation of Amyloid Fibrils of $\beta_{2}$-Microglobulin
}

Kei-ichi YAMAGUCHI, Yuji GOTO

Institute for Protein Research, Osaka University 
プチドが, 適当な条件下でアミロイド線維を形成する ことがわかってきた22,5). 乥こで, アミロイド線維形成 はポリペプチド鎖の基本的性質と考えられるようにな りつつある (Fig.1). アミロイド線維の形成機構の解明 は, アミロイドーシスの予防や治療法開発のために重 要である.さらに, アミロイド線維を形成することがタ ンパク質の本質的な性質であるとすると, 弚れを研究 することは構造生物学的にも重要である. 本稿では, 透 析アミロイドーシスの原因タンパク質である $\beta_{2}$ ミクロ グロブリンについて, 最近, 筆者らが行った研究を中心 にアミロイド線維形成の分子機構について紹介する.

\section{2 . 透析アミロイドーシス}

長期透析患者に高頻度で発症する合併症に, 透析アミ ロイドーシスがある. 本疾患では, $\beta_{2}$ ミクログロブリン からなるアミロイド線維が, 手根管や肩を中心に全身 の関節部位に蓄積し, 弚の結果, 関節の痛みや屈折障害 を招く ${ }^{6)} . \beta_{2}$ ミクログロブリンは 99 アミノ酸残基から なる典型的な免疫グロブリンドメイン・フォールドを もつタンパク質であり, 分子中央に存在する 1 本のジス ルフィド結合が 2 層の $\beta$ シートをつなぎ, 安定化してい る7) (Fig.2a)． $\beta_{2}$ ミクログロブリンは本来クラスI組織 適合性抗原の軽鎖であり, 免疫機能には必須のタンパ ク質である. 健常者では, さまざまな細胞から血液中に 放出された $\beta_{2}$ ミクログロブリンは, 腎藏で代謝される. 腎不全の患者では代謝が行われず,ささらに, 血液透析患 者では透析膜を通過しないため, 血中から除去されな い.このため, 健常者では約 $1 \mathrm{mg} / \mathrm{L} て ゙ あ る \beta_{2}$ ミクログロ ブリンの血中濃度が, $50 \mathrm{mg} / \mathrm{L}$ 程度に上昇する. このよ うな状態が 10 年以上も続くと多くの患者でアミロイド 線維の沈着が起きる. $\beta_{2}$ ミクログロブリンの血中濃度 の上昇がアミロイドーシス発症の第 1 の危険因子であ ることは間違いないが, なぜ 10 年以上経過して発症す るのかをはじめ, 詳細な機構はわかっていない.

透析アミロイドーシスは, 透析医療の盛んな我か国で 特に頻発している病気である. 乥して, 透析アミロイド ーシスは, 優れた医療の引き起こした思いもしなかっ た合併症であり, 医原病の1つである.さまざまなタン パク質がアミロイド線維を形成することを考えると, $\beta_{2}$ ミクログロブリンのような隠れた危険性をもつタンパ ク質はほかにも数多く存在するはずである. 兴の意味 で, 透析アミロイドーシスは医療に対する警鐘を鳴ら すものである. アミロイドーシス発症の分子機構を解 明して, 新たな医原病を防ぐことが必要である.
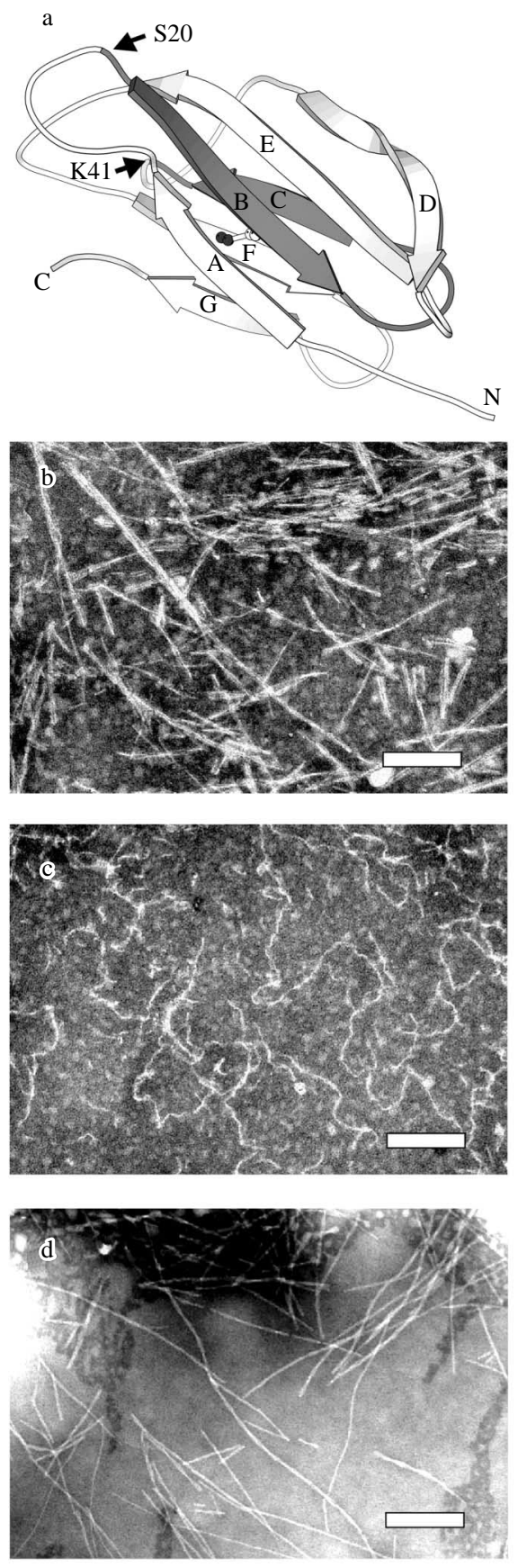

Fig.2 Various conformational states of $\beta_{2}$-microglobulin. ( a) The native state with the PDB file $3 \mathrm{HLA}^{7}$. The region corresponding to K3 peptide ( Ser20-AsnPhe-Leu-Asn-Cys-Tyr-Val-Ser-Gly-Phe-His-Pro-SerAsp-Ile-Glu-Val-Asp-Leu-Leu-Lys41) is labelled gray. $(\mathrm{b}-\mathrm{c})$ Electron micrographs of fibrillar states : ( $b$ ) mature fibrils, (c) immature fibrils and (d) K3 fibrils. The scale bars represent $200 \mathrm{~nm}$. ( 文献 17 より許可 を得て転載) 


\section{3. シード依存性伸長反応}

$\beta_{2}$ ミクログロブリンは比較的小さな球状タンパク質 であるので, タンパク質の立体構造とアミロイド線維 形成との関係を物理化学的な手法で研究するのに適し ている. このため, 近年, 著者らをはじめいくつかのグル 一プが, 活発な研究を展開している ${ }^{8)-10)}$. アミロイド線 維形成はきわめて普遍的な現象であり, $\beta_{2}$ ミクログロ ブリンで得られた知見もほかのタンパク質のアミロイ ド線維に共通すると考えられる.

アミロイド線維を形成する能力をもつタンパク質は アミロイド原性タンパク質 (amyloidogenic protein) と よばれる. 内木らは, $\beta_{2}$ ミクログロブリンをはじめとす るいくつかのアミロイド原性タンパク質において, 破 砕して断片化したアミロイド線維をシードとして用い ることによって, 比較的短時間でアミロイド線維を形 成できることを示した ${ }^{11}$. . シード依存性アミロイド形 成反応は, アミロイド線維の形成機構の特徵を反映し た重要な反応である. $\beta_{2}$ ミクログロブリンの例では, ま ず, 患者から精製したアミロイド線維を超音波破砕し て線維断片を作製し，これをシードとして用いる.これ に酵母あるいは大腸菌で発現した $\beta_{2}$ ミクログロブリン のモノマーを加えると,ただちにアミロイド伸長反応 が起きる. ただし, 以上の操作はすべて酸性 $(\mathrm{pH} 2.5)$ で行う. pH 2.5 では $\beta_{2}$ ミクログロブリンは酸変性して おり, タンパク質のネイティブ構造か変性することが アミロイド線維形成に必要であることを示す.

\section{4 . $\beta_{2}$ ミクログロブリンのさまざまなアミロイド 線維}

1つのアミロイド原性タンパク質がいくつかの異な る線維状構造を形成することが知られている. $\beta_{2}$ ミク ログロブリンにおいてもいくつかの線維形態を観察す ることができる.すでに述べたように, 酸性でのシード 依存アミロイド伸長反応によって, 患者から精製した アミロイド線維に近い剛直なアミロイド線維が形成さ れる (Fig.2b). 他方, $\beta_{2}$ ミクログロブリンを酸性溶液 中, 高塩濃度下に長時間置くと, シードが存在しない条 件下で, くねくねと折れ曲がったフィラメント状のも のができる ${ }^{12)}($ Fig.2c $)$.ここではフィラメントとよぶ． 細いフィラメントはいくら時間か経過しても剛直なア ミロイド線維へと変化することはなかった. お光らく, 高塩濃度下で分子間の疎水性相互作用か強まり, 線維 形成におけるさまざまな相互作用のバランスが崩れて, 協同的な線維形成ができず, 中間的な構造で行き止ま ってしまったのであろう (アミロイド繊維形成の協同 性についてはp.235の用語コラム参照). しかしながら, このような中間的構造か観測されたことから,アミロ イド線維は何本かのフィラメントか寄り集まってでき ていると推定される.

他方, $\beta_{2}$ ミクログロブリンをプロテアーゼで限定分解 し, 得られる部分ペプチドのアミロイド線維形成につい て調べたところ, Ser20-Lys41からなる22残基のペプチ ド (K3) 単独でも, 全長 $\beta_{2}$ ミクログロブリンと類似し たアミロイド線維を形成することが明らかとなった ${ }^{13}$. この領域はアミロイド線維形成において重要であり, 線維形成の引き金になると考えられる. K3ペプチドは シードを必要とせず, 自発的に重合してアミロイド線維 を形成する. 電子顕微鏡を用いて観察すると, $\beta_{2}$ ミクロ グロブリンの剛直な線維に似た直線状の細長いアミロ イド線維が形成されていた (Fig.2d). K3 ペプチドがフ レキシブルなフィラメントを形成することはなかった.

なお, 全長 $\beta_{2}$ ミクログロブリンのアミロイド線維形 成反心は $\mathrm{pH} 2$ 付近に極大があるのに対して, K3 の最適 $\mathrm{pH}$ は中性付近にあった ${ }^{14)}$. 全長 $\beta_{2}$ ミクログロブリンが 酸性条件下でのみアミロイド線維を形成するのは, 中 性では $\beta_{2}$ ミクログロブリンがネイティブ構造を形成し ており, K3 領域が表面に露出しないためだと考えられ る. よって, ネイティブ構造の崩壊あるいは不安定化に より K3 の領域か露出し, 核形成の成立などの条件さえ 整えば, 中性 $\mathrm{pH}$ においても $\beta_{2}$ ミクログロブリンのアミ ロイド線維形成が起きると予想される。

\section{5 . アミロイド線維の構造解析}

上で述べた 3 種類の線維の構造を比較すれば, アミロ イド線維形成を理解する手がかを得ることができる と期待される. しかしながら, アミロイド線維は非結晶 であるためX線結晶構造解析を用いることはできない． また, 高分子重合体であるため溶液 NMR 解析にも適さ ない. 現在, 固体NMRがアミロイド線維の構造を原子 分解能で調べることができる方法である ${ }^{15)}$. 他方, 球状 タンパク質では, ペプチド結合を形成するアミドプロ トンの水素/重水素交換と NMR 解析を組み合わせて, アミノ酸残基レベルでタンパク質の柔軟性を解析する ことが盛んに行われている. 水素結合を形成して $\alpha$ へリ ックスや $\beta$ ッートな゙の 2 次構造に関与しているアミ ドプロトンの交換㯈度は, 数千から数百万倍まで遅く なる.つまり, 重水素との交換反応を追跡することによ り, タンパク質分子の固さ・やわらかさを残基ごとに 調べることができる. このため, 重水素交換を, 高分子重 合体であるアミロイド線維の解析に利用することを考 えた ${ }^{16), 17) .}$ 


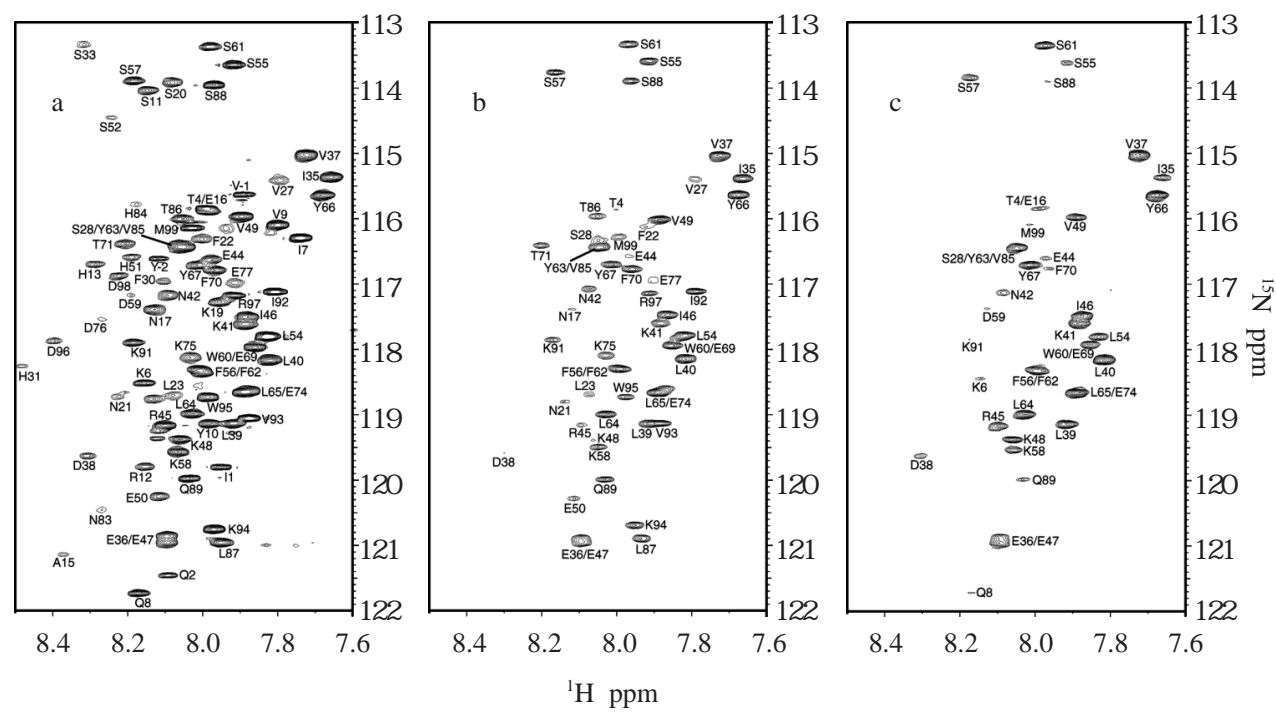

Fig.3 ${ }^{1} \mathrm{H}-{ }^{15} \mathrm{~N}-\mathrm{HSQC}$ spectra of $\beta_{2}$-microglobulin dissolved in $95 \%(\mathrm{v} / \mathrm{v}) \mathrm{d}_{6}$-DMSO, $5 \%(\mathrm{v} / \mathrm{v}) \mathrm{D}_{2} \mathrm{O}$ and $0.2 \%(\mathrm{v} / \mathrm{v}) \mathrm{d}_{2}$ dichloroacetate ( pD 5.0).( a) Reference spectrum obtained for the sample that was not subjected to exchange, ( b) mature fibrils after 204 hours from the start of the exchange, and (c) immature flexible filaments after 204 hours. ( 文献 17 より許可を得て転載)

ジメチルスルホキシド $\left[\left(\mathrm{CH}_{3}\right)_{2} \mathrm{~S}=\mathrm{O}\right.$ ；DMSO] は 強い極性溶媒であり, 高濃度のDMSOはアミロイド線 維を溶かす能力が高い. 都合のよいことにDMSO は夕 ンパク質のアミドプロトンと交換する水素原子を含ま ないので, 重水素交換反応を停止することにもなる. DMSO によるアミロイド線維溶解と溶液 NMR を組み 合わせることによって,アミロイド線維の構造を残基 レベルで解析することができる. (1)まず, アミロイド線 維の重水素交換を行う. (2)次にアミロイド線維を遠心 分離回収し, 凍結乾燥する. (3) 95 \% ( $/ \mathrm{v} / \mathrm{v})$ DMSO, 5 \% $(\mathrm{v} / \mathrm{v}) \mathrm{D}_{2} \mathrm{O}, \mathrm{pD} 5.0$ に溶解後, NMR スペクトルを測定し て, 重水素交換反応を定量する.

この手法を用いて, $\beta_{2}$ ミクログロブリンの形態が異な る2種類の線維構造 (剛直なアミロイド線維とフレキ シブルなフィラメント ) と K 3 ペプチドのアミロイド線 維に対して, 重水素交換実験を行った. DMSO中での重 水素交換の定量は, $\beta_{2}$ ミクログロブリンは ${ }^{1} \mathrm{H}^{-15} \mathrm{~N}$ HSQC スペクトル* (Fig.3), K3 ペプチドは ${ }^{1} \mathrm{H}-{ }^{-} \mathrm{H}$ TOCSY ス ペクトル*を測定して行った. K3ペプチドは残基数が 少ないので, ${ }^{1} \mathrm{H}-{ }^{-1} \mathrm{H}$ TOCSY スペクトル上でもピークの 重なりが少なく, 重水素交換を追跡することができる. 通常の酸変性タンパク質では, 重水素交換はきわめて 速く進み, 数時間でほとんどのピークは消失する. 8 日 間交換を行ったアミロイド線維 (Fig.3b) やフィラメ ント $($ Fig.3c) で多くのピークか観測できたことは, こ れらの構造か洨換から強く保護されていることを示す.
一定時間後の重水素交換の割合をアミノ酸残基に対し てプロットし, 全長アミロイド線維, 全長フィラメント, K3アミロイド線維を比較した (Fig.4).3 種類のアミロ イド線維は光れ艺れに特徵的な強度の減少を示した。

剛直な全長アミロイド線維では, $N$ 末端を除く広範囲 のアミドプロトンが交換から強く保護されていた (Fig.4a). しかし, C 末端の保護の程度は, 中央部分より 低い. アミロイド線維のプロテアーゼ分解などの結果 ${ }^{181}$ と比較すると, C 末端は線維形成にかかわっていない可 能性が高い. また, $\beta_{2}$ ミクログロブリンのネイティブ状 態について重水素交換実験を行うと,おもに コア領域だけが交換から保護されていた ${ }^{19)}$. 剛直なア ミロイド線維では, 弚れに加えてループ領域も交換か ら強く保護されている.つまり,アミロイド線維では, ネ イティブ構造のループ領域もßシートを形成し, 水素結 合で安定化されている可能性が高い.

他方, 高塩濃度下て形成したフレキシブルなフィラメ ントでは, 重水素交換から保護されている領域が狭く, Val37-Lys48 と Ser57-Asp69付近の2 カ所だけか強く保 護されていた $\left(\right.$ Fig.4b). 別の言い方をすると, $\beta_{2}$ ミクロ グロブリンと $\mathrm{K} 3$ ペプチドの剛直なアミロイド線維で は $80 \%$ \%上の残基が保護されていたが, フレキシブル なフィラメントでは 30 \% 程度しか保護されていなかっ た.フィラメントでは線維形成にかかわっている残基 が少なく, このため剛直な形状を保てないと考えられ る. また, この2つの部位は疎水性が高い領域と一致す 

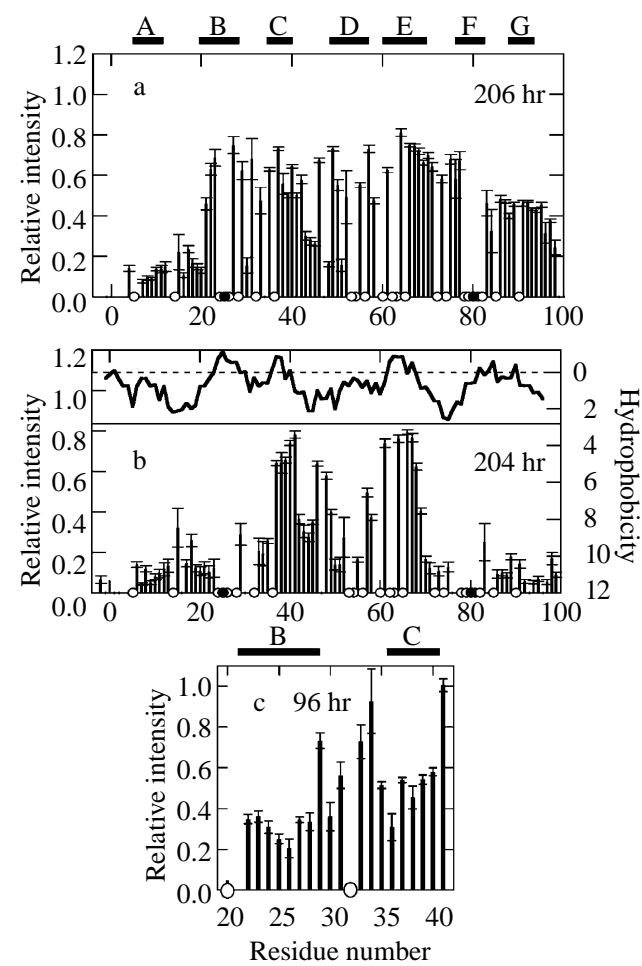

Fig.4 The ratios of peak height with and without exchange in deuterated buffer plotted against residue number.

( a) Mature fibrils, ( b) immature flexible filaments and (c) K3 fibrils. The exchange time was indicated in hour. The position of the cysteine residues involved in the disulfide bond (Cys25-Cys80) and the residues, for which data were not available, are indicated by closed and open circles, respectively. Hydropathy profile calculated using the scale of Kyte and Doolittle ${ }^{21)}$ is shown in ( b). The locations of secondary structures obtained from the X-ray structure are indicated on the top of the figure.( 文献17より許可を得て転載)
る. 高塩濃度下で強まった疎水性相互作用によって, フ レキシブルなフィラメントが形成されたのであろう. これに対して, K3ペプチドのアミロイド線維では,ペプ チド全体が同樣に重水素交換から保護されていた (Fig.4c). フレキシブルな領域か削除され, ペプチド全 体か強固な水素結合ネットワークを形成していると考 えられる.

球状タンパク質のアミドプロトンの重水素交換は, 各 残基について1次反応に従うことが多い.ところが, ア ミロイド線維の重水素交換反応を詳細に解析すると光 の機構は複雑であった.つまり, 交換反応は単純な1次 反応とはならず, 約 8 日の交換反応で交換しなかった分 画は,さらに反応時間を長くしても交換しなかった. こ れより,アミロイド線維を構成するタンパク質分子は, 交換から比較的強く保護された状態と, きわめて強く 保護された状態の少なくとも2つの混合状態にあるこ とがわかった.

\section{6. アミロイド線維のモデル}

線維構造の中て環境の異なるモノマー分子が共存す ることは, アミロイド線維か数本のプロトフィラメン トがより合わさった超分子構造体であることとよく合 つている. 同じモノマー分子でも, 線維の表面にあるも のと線維の内部に存在するものが存在し, 内部にある 分子のアミドプロトンは周りの溶媒との接触がまった くなく, 重水素交換からきわめて強く保護されている のであろう (Fig.5a). これはアミロイド線維の超分子 構造がもたらす基本的な特徵であり, 球状タンパク質 とは基本的に異なる。

次に, K3 (Ser20-Lys41) ペプチドのアミロイド線維, 全長 $\beta_{2}$ ミクログロブリンのフレキシブルなフィラメン 卜と剛直な線維を比べると, アミロイド線維の形成機

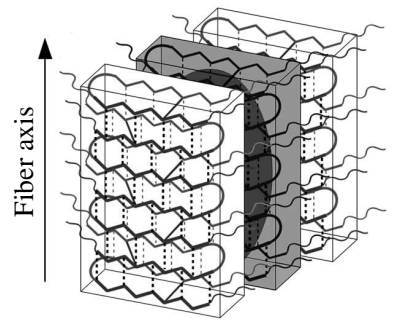

(a)

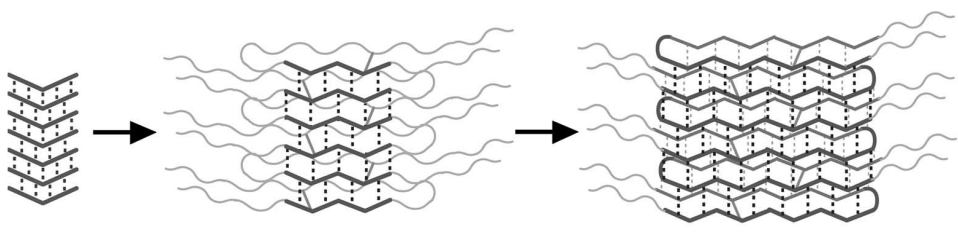

(b)

Fig.5 Schematic models of amyloid fibrils. ( a) A model consistent with the biphasic fibrillar H/D exchange kinetics. Amyloid fibrils are formed with several pieces of protofilament. Dotted lines indicate hydrogen bonds. Outer sides of protofilaments, shown in light color, can be exchanged relatively easily, while the inner side of the protofilaments, shown in dark color, are not subject to $H / D$ exchange. ( b) Protected and unprotected regions of different states: K3 fibril ( left), immature filament ( middle), and mature fibril ( right). The distinct core regions among the three fibrillar states suggest that, firstly, the $\beta$-sheet cores are formed in K3 region, and then propagate to the rest of the molecule.( 文献17より許可を得て転載) 
構を推定することができる. まず, K3 領域は単独でもア ミロイド線維を形成することから, K3 領域は線維形成 の開始点となる可能性が高い.K3 領域で形成された水 素結合ネットワーク ( $(\beta$ シート構造) は分子全体に広 がり, 全長 $\beta_{2}$ ミクログロブリンの剛直なアミロイド線 維か形成されると推定される (Fig.5b).

\section{7 .おわりに}

アミロイド線維の研究は, 驚くべき勢いで展開してい る. 極低温電子顕微鏡 4$)$ や固体 $\mathrm{NMR}^{15}$ に により, アミロ イド線維の立体構造の解析も進んでいる. 弚れでも $\mathrm{X}$ 線結晶解析や溶液 NMR 解析に基づくネイティブ構造 の詳細な立体構造にはほど遠い. 今回, アミロイド線維 に対して重水素交換を行うことで, 線維形成にかかわ っている残基を明らかにすることができた. 分解能は 低いが, 構造物性を残基レベルで議論できる点で有用 な方法である.

アミロイド線維形成は多くのタンパク質やペプチド に共通した特徵であることは間違いない (Fig.1) . ネイ ティブ構造がタンパク質の機能を支える華やかな表の 世界だとすると,アミロイド線維は病気と関係するタ ンパク質の裏の世界である. しかしながら, 裏の世界の タンパク質も決して暗いだけではない. アミロイド線 維は折れ曲がりや枝分かれのない剛直なワイヤーであ り, ナノテクノロジーの素材として期待されている. DNAの二重らせんは特徵的な構造を活かし, 電流を流 すことができる. 同樣にアミロイド線維を利用したナ ノワイヤーの試みも報告されている201. DNA は4つの 塩基からなるが, タンパク質は 20 種類のアミノ酸から なり, 产の組み合わせ次第では可能性は大きく広がる. 線維を形成するタンパク質のアミノ酸配列を操作する ことにより, 太さや硬さの異なるさまざまな形態のア ミロイド線維を作れるのではないかと想像する. さら に, アミロイド線維の形態を自在に操ることができれ ば, 複雑な材料への応用も期待できる.

\section{謝 辞}

本稿て紹介した著者の研究は, 加藤秀典博士 (奈良先 端科学技術大学院大学), 星野大博士 (蛋白質研究所), 内木宏延教授・長谷川一浩博士 (福井大学) らとの共 同研究による成果であり,これらの方々に感謝致します.

\section{文 献}

1) 後藤祐児, 谷澤克行 (2000) タンパク質の分子設計 (後藤・谷澤編), pp.1-35, 共立出版.

2) Dobson, C. M. (2003) Nature 426, 884-889.

3）樋口京一 (2001) 分子シャペロンによる細胞機能制御 (永田, 森, 吉田編), pp.164-174, シュプリンガーフェア ラーク東京.

4) Jiménez, J. L. et al. (2002) Proc. Natl. Acad. Sci. USA 99, 9196-9201.

5) Ohnishi, S., Koide, A. and Koide, S. (2000) J. Mol. Biol. 301, 477-489.

6) Gejyo, F. et al. (1985) Biochem. Biophys. Res. Commun. 129, 701-706.

7) Bjorkman, P. J. et al. (1987) Nature 329, 506-512.

8) Rasano, C. et al. (2004) J. Mol. Biol. 335, 1051-1064.

9) McParland, V. J., Kalverda, A. P., Homans, S. W. and Radford, S. E. (2002) Nature Struct. Biol. 9, 326-331.

10) Kad, N. M. et al. (2003) J. Mol. Biol. 330, 785-797.

11) Naiki, H. et al. (1997) Amyloid 4, 223-232.

12) Hong, D. P., Gozu, M., Hasegawa, K., Naiki, H. and Goto, Y. (2002) J. Biol. Chem. 277, 21554-21560.

13) Kozhukh, G. V.et al. (2001) J. Biol. Chem. 277, 13101315.

14) Ohhashi, Y., Hasegawa, K., Naiki, H. and Goto, Y. (2004) J. Biol. Chem. 279, 10814-10821.

15) Tycko, R. (2003) Biochemistry 42, 3151-3159.

16) Hoshino, M. et al. (2002) Nature Struct. Biol. 9, 332-336.

17) Yamaguchi, K. et al. (2004) J. Mol. Biol. 338, 559-571.

18) Monti, M. et al. (2002) Protein Sci. 11, 2362-2369.

19) Katou, H. et al. (2002) Protein Sci. 11, 2218-2229.

20) Scheibel, T. et al. (2003) Proc. Natl. Acad. Sci. USA 100, 4527-4532.

21) Kyte, J. and Doolittle, R. F. (1982) J. Mol. Biol. 157, 105-132. 


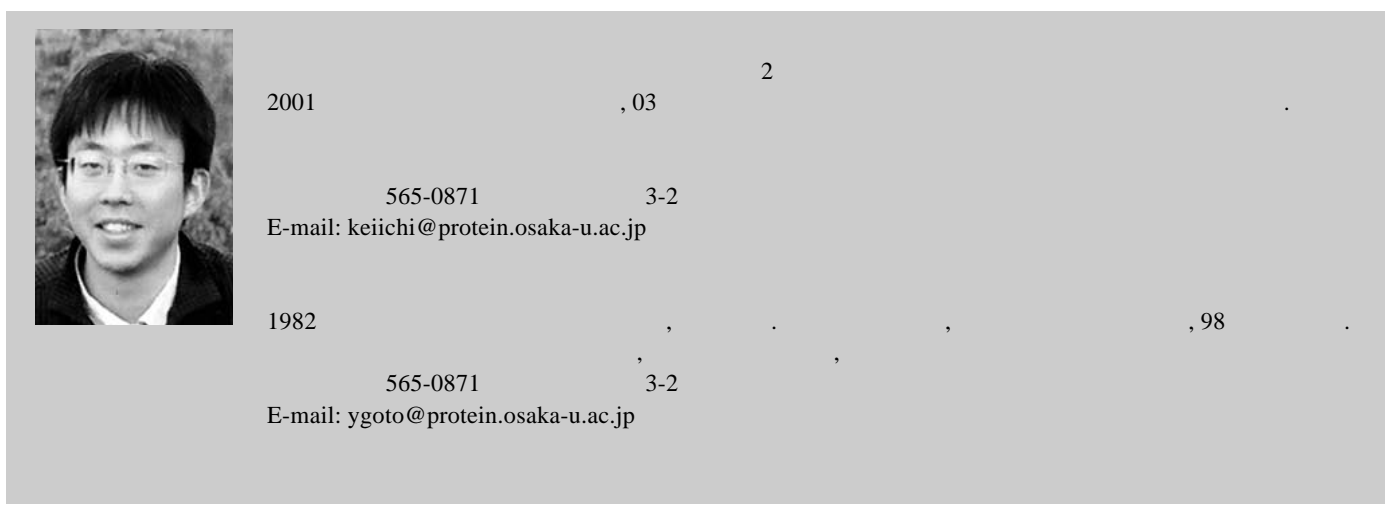

